\title{
Foreign Exchange Reserves Accumulation in Latin America during the Current Crisis
}

Acumulación de Reservas de divisas en América Latina durante la actual crisis

\section{Resumen}

A pesar del mínimo crecimiento económico en los países de América Latina de 2006 en adelante, mucho de ellos han acumulado reservas internaciones. En la literatura se pueden encontrar tres causas por las cuales se acumulan reservas: (1) el pago de la deuda a corto plazo, (2) el pago de por lo menos tres meses de importaciones, y (3) la protección de una eventual salida de capitales y problemas en el tipo de cambio. No obstante, la mayoría de los países de América Latina cumple los tres criterios. ¿Por qué entonces algunos países latinoamericanos siguen acumulando reservas? Nuestra respuesta es que para algunos gobiernos, el atesoramiento podría representar una expresión social de la riqueza en el corto plazo, distinción que hizo Marx para economías no consideradas capitalistas.

\footnotetext{
Palabras clave:

- Finanzas internacionales

- Bancos centrales y sus políticas
}

- Prestamos Internacionales

\begin{abstract}
Even though several Latin American countries have shown recently poor economic performance, many of them have accumulated foreign exchange reserves from 2006 onwards. Conventionally, three reasons are given for international reserves accumulation: (1) payment of short-term debt, (2) payment of at least three months of imports, and (3) protection for an outflow of capital. However, the majority of the Latin American countries meet all three criteria. Why then do some Latin American countries continue to accumulate reserves? Our answer is that for some governments, hoarding might represent a social expression of wealth, following Marx's ideas

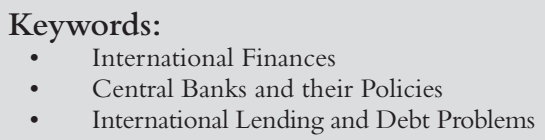

Víctor Manuel Isidro Luna**

JEL: F3, E58, F34

\section{Introduction}

Even though several Latin American countries have shown recently poor economic performance, many of them have accumulated foreign exchange reserves from 2006 onwards. Conventionally, three reasons are given for international reserves accumulation: (1) payment of short-term debt, (2) payment of at least three months of imports, and (3) protection for an outflow of capital. However, the majority of the Latin American countries meet all three criteria. Why then do some Latin American countries continue to accumulate reserves? Our answer is that for some governments, hoarding might represent a social expression of wealth, following Marx's ideas. After this introduction, Section 2 describes the economic performance of Latin America, the us, Germany, and Japan. In Section 3, we highlight the increasing amount

* Profesor de asignatura Facultad de Economía, UnAm e Instituto Politécnico Nacional Ph.D. Economics. University of Utah. victor.isidro@utah.edu 
in reserves as percent of GDP in Latin America and some developed countries. Section 4 advances a theoretical explanation for accumulating foreign exchange reserves. In Section 5, we present concluding remarks.

\section{Economic growth performance}

In 2007, the deepest world crisis since the Great Depression started and has continued with neither a theoretical nor a practical solution to date. However, in contrast to the 1980s and 1990s, the crisis was precipitated by advanced countries - not poor countries. Analyzing economic growth during the period of neoliberalism, the following patterns can be distinguished (see Table 1):

(1) Latin America lost decade from 1981 to 1990 after debt crises; growth rates were on average 1.4 percent. Never has the area undergone a period of stagnation of that magnitude after wwII. From 1991 to 1995, Latin America experienced a recovery, due to implementation of neoliberal policies. However, after a short-term boom, economies plummeted for nearly a decade, from 1996 to 2005 . During this time, the growth rate averaged 2.8 percent. In spite of a sharp decline of gdp in 2009 in the region, from 2006 onwards the area has grown, with disparities, 3.5 percent.

(2) The performance of advanced countries during the 1980s was far better than that of Latin American countries. However, from 1991 onwards, advanced economies, especially Germany and Japan, slowed drastically. Germany from 2001 onwards has grown 1.1 percent and Japan 0.87 percent. The us has seen 1.78 percent growth. Even though the us performance has been better than that of Europe and Japan, 1.78 percent was the worst performance under neoliberalism.1

(3) Latin America is growing faster than the us as an area in the last 9 years. However, Table 1 shows that Brazil and Mexico have grown at a very slow rate. Brazil and Mexico have, historically, accounted for around 70 percent of Latin America's GDP, so the recent slow rate of growth is not good news.

(4) In 1980, A. Lewis (1980) proposed that the engine of growth for underdeveloped countries was trade. As long as advanced economies underwent expansion, underdeveloped economies could grow at a high level. Also, as long as the majority of the Latin American countries had weak domestic markets, the

${ }^{1}$ Roberts (2009) notes two trends under neoliberalism in the Us economy. First, from 1982 to 1997 , profit rate increased, and then growth rate was 3.5 percent. Second, from 1998 to present day, profit rate has declined, and then growth rate was 2.6 percent. At the moment, the us would be at the bottom of the crisis. 
only option to grow would be to increase interregional cooperation through trade in underdeveloped countries.

(5) Neoliberalism, has fueled the shift in Latin American economies to attempt to increase exports (Williamson 1990), mainly commodities. Domestic markets have not gotten wider, real wages have not increased, income distribution has not improved, and interregional cooperation among underdeveloped countries has not succeeded. It would seem that economic growth in Latin America depends on external factors. However, Latin American GDP in several countries has been stagnant.

(6) Finally, China has grown consistently from 1981 onwards.

\section{Table I}

\section{Growth in Countries around the World}

\begin{tabular}{|l|c|c|c|c|c|c|}
\hline \multicolumn{1}{|c|}{ Countries } & 1981-1990 & 1991-1995 & 1996-2000 & 2001-2005 & 2006-2010 & 2011-2013 \\
\hline Argentina & -1.4 & 6.7 & 2.7 & 2.4 & 5.7 & 4.1 \\
\hline Brazil & 1.6 & 3.1 & 2.0 & 2.8 & 4.5 & 2.1 \\
\hline Colombia & 3.6 & 4.1 & 1.3 & 3.6 & 4.6 & 5.1 \\
\hline Chile & 3.9 & 8.7 & 4.2 & 4.2 & 3.5 & 5.1 \\
\hline Mexico & 1.9 & 2.2 & 5.1 & 1.7 & 2.0 & 3.0 \\
\hline Peru & -0.7 & 5.3 & 2.6 & 4.3 & 6.9 & 6.1 \\
\hline Uruguay & 0.2 & 4.0 & 3.0 & 0.3 & 5.7 & 5.1 \\
\hline Venezuela & 0.9 & 3.5 & 0.8 & 3.1 & 3.8 & 3.7 \\
\hline Latin America & 1.4 & 3.4 & 3.1 & 2.5 & 3.8 & 3.2 \\
\hline Us & 3.4 & 2.6 & 4.3 & 2.5 & 0.8 & 2.0 \\
\hline Germany & 2.3 & 2.0 & 1.9 & 0.6 & 1.3 & 1.4 \\
\hline Japan & 4.6 & 1.4 & 0.9 & 1.2 & 0.4 & 1.0 \\
\hline Adv. Countries & 3.5 & 2.2 & 3.1 & 1.9 & 0.8 & 1.7 \\
\hline China & 9.3 & 12.3 & 8.6 & 9.8 & 11.2 & 8.2 \\
\hline
\end{tabular}

Source: World Bank

\section{Foreign exchange reserve accumulation}

From 2008 through 2009, several countries had abrupt declines in gdp, along with problems in other economic variables such as unemployment, current account deficits, and the evolution of the profit rate. In 2008, the us gdp declined -0.3 percent, and Japan saw a decline of -1.0 percent. Meanwhile, in 2009 , the growth rate in Germany was -5.6 percent, -in Japan -5.5 percent, 
in the us -2.8 percent, and in Brazil -0.3 percent. The deepest crisis in Latin America occurred in Mexico, which had a growth rate of -4.7 percent (and one of the worst performances in the region). It is evident that developed as well as underdeveloped countries suffered after 2007. Some scholars such as Wolf (2004), Collier and Dollar (2002), Bernake (2004), and Cotis (2007) (quoted in Keen 2011) have pointed out that globalization has benefited developed countries only, but this argument is now challenged with the current economic crisis because the economies of the $\mathrm{US}^{2}$ and the majority of the European countries have stagnated and are characterized by high unemployment and blatant inequality.

However, a worldwide phenomenon that has garnered attention is the increasing foreign exchange reserves in underdeveloped countries, concomitant to the low level of reserves in the majority of advanced countries. From 1981 to 2000, foreign exchange reserves in Latin America as a percent of GDP were around 5.9 to 7.7 percent. Since 2006 foreign exchange reserves have almost doubled as a percent of GDP, the most significant cases being Brazil, Mexico, and Peru (See Table 2).

Table 2

Foreign Exchange Reserves as Percent of GDP

\begin{tabular}{|l|c|c|c|c|c|c|}
\hline \multicolumn{1}{|c|}{ Countries } & 1981-1990 & 1991-1995 & 1996-2000 & 2001-2005 & 2006-2010 & 2011-2013 \\
\hline Argentina & 5.0 & 5.1 & 6.8 & 9.1 & 12.3 & 6.8 \\
\hline Brazil & 2.9 & 5.8 & 5.9 & 7.4 & 12.2 & 15.6 \\
\hline Colombia & 11.0 & 13.2 & 9.4 & 11.0 & 10.0 & 10.3 \\
\hline Chile & 15.4 & 22.1 & 20.5 & 18.3 & 12.5 & 15.7 \\
\hline Mexico & 3.8 & 4.4 & 5.6 & 7.6 & 9.5 & 13.7 \\
\hline Peru & 10.6 & 12.8 & 18.8 & 18.1 & 26.0 & 31.5 \\
\hline Uruguay & 20.3 & 9.5 & 10.2 & 14.8 & 20.1 & 26.1 \\
\hline Venezuela & 19.9 & 22.3 & 17.8 & 17.8 & 13.2 & 7.0 \\
\hline Latin America & 5.9 & 7.1 & 7.7 & 9.2 & 11.9 & 13.9 \\
\hline Us & 3.4 & 2.4 & 1.6 & 1.4 & 2.3 & 3.3 \\
\hline Germany & 9.2 & 5.3 & 4.6 & 3.9 & 4.6 & 6.2 \\
\hline Japan & 3.0 & 2.6 & 6.0 & 14.8 & 21 & 23 \\
\hline Adv. Countries & 6.4 & 2.9 & 3.2 & 4.9 & 6.6 & 8.0 \\
\hline China & 7.2 & 9.2 & 14.5 & 26.3 & 45.2 & 42.6 \\
\hline
\end{tabular}

Source: World Bank

${ }^{2}$ The Us has suffered less. 


\section{A theoretical explanation}

Brazil, Mexico, Colombia, Chile, Uruguay, and Peru have increased their foreign exchange reserves as a percent of GDP from 2006 onwards, but Brazil and Mexico have produced minimal economic growth. With the hoarding carried out by Latin American countries, these countries have bought T-bills and other financial assets, resulting in a situation in which underdeveloped countries might finance developed ones, particularly the Us. In 2012, among the biggest buyers of T-bills worldwide, Brazil was number 5, Mexico was number 14, and Colombia and Chile were numbers 28 and 30, respectively (see Figure 1). Beginning in 2005, all four countries have increased their purchases of treasury bonds. Why have some countries of Latin America pursued a policy of international reserves accumulation with a minimal growth rate?

\section{Figure I}

\section{Latin America's T-Bills accumulation as a percent of GDP}

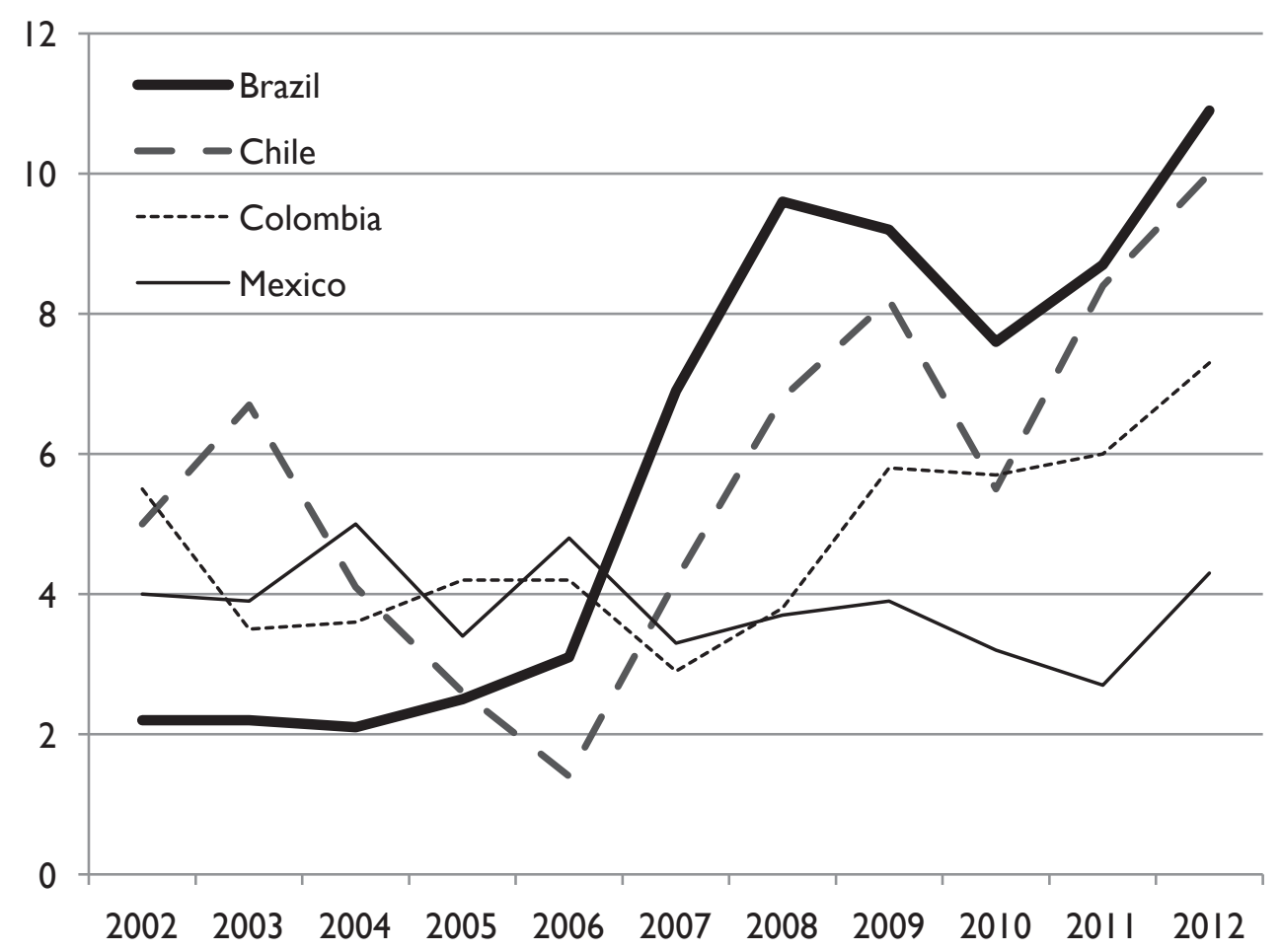

Source: U.S. Department of the Treasury 2014 
The economic literature conventionally identifies three reasons countries hoard (See Bird and Rajan 2003; Rodrik 2006; Lanteri 2014). The first is to ensure payment of short-term debt (usually one year), which is the so-called Guidotti-Greenspan rule. As shown in Figure 2, all Latin American countries, except Argentina, have reduced their short-term debt level with respect to their foreign exchange reserve from the late 1990s to the present day. This fact, according to Rodrik (2014), helps countries to borrow more easily and avert a crisis.

Figure 2

\section{Ratio of short-debt to foreign exchange reserves}
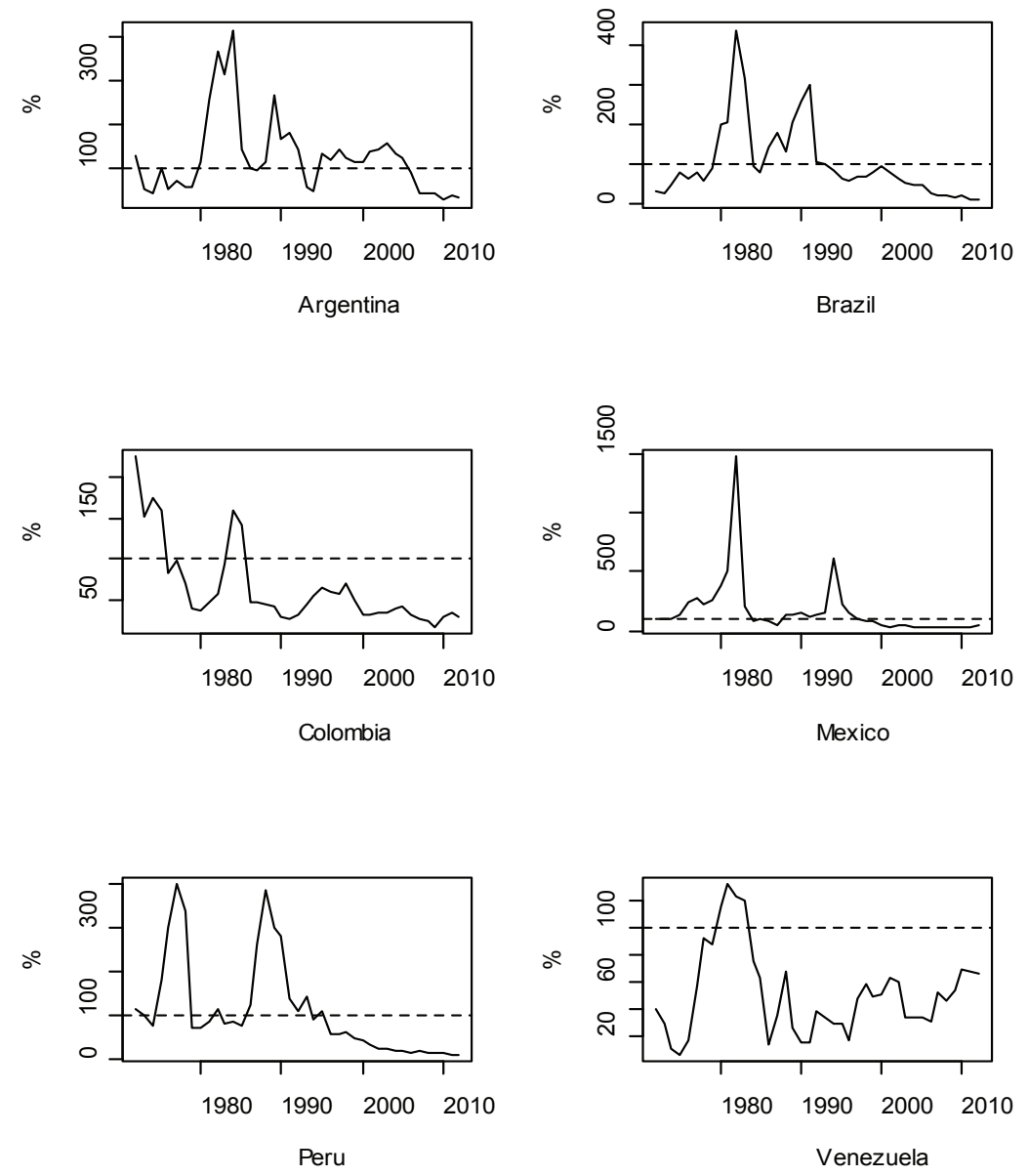

Source: Author's elaboration with data from WorldBank (2014). 
A second reason for international reserves accumulation takes into account each country's participation in international trade. Payment of three months of imports is considered an appropriate level (Rodrik 2006; Bird and Rajan 2003). According to Rodrik (2006), this ratio had fluctuated around 3 during the 1990s in almost all the underdeveloped countries. Currently, countries such as Brazil, Peru, and Uruguay have ratios higher than 10. Colombia, Mexico, and Chile have ratios between 3 and 4, and in Argentina and Venezuela the ratio has deteriorated but is still above the level that is considered appropriate (See Table 3).

\section{Table 3}

\section{Ratio of Foreign Exchange Reserves to Imports}

\begin{tabular}{|l|c|c|c|c|c|c|c|c|}
\hline \multicolumn{1}{|c|}{ Countries } & 2005 & 2006 & 2007 & 2008 & 2009 & 2010 & 2011 & 2012 \\
\hline Argentina & 7.3 & 7.3 & 8.4 & 6.9 & 9.3 & 7.6 & 5.3 & 5.3 \\
\hline Brazil & 5.1 & 6.7 & 10.9 & 8.5 & 13.2 & 11.9 & 11.7 & 12.8 \\
\hline Chile & 4 & 3.5 & 2.6 & 3.1 & 4.4 & 3.6 & 4.6 & 4.5 \\
\hline Colombia & 5.7 & 4.9 & 5.3 & 5 & 6.1 & 5.6 & 4.8 & 5.1 \\
\hline Mexico & 3.3 & 3 & 3.1 & 3.1 & 4.3 & 4.1 & 4.4 & 4.6 \\
\hline Peru & 8.2 & 7.9 & 9.9 & 8.4 & 11.3 & 11.0 & 10.2 & 12.5 \\
\hline Uruguay & 6.4 & 5.3 & 6 & 6.4 & 9.9 & 7.6 & 8.3 & 10 \\
\hline Venezuela & 9.9 & 9 & 6.2 & 7.1 & 6.9 & 5.9 & 4.7 & 3.9 \\
\hline
\end{tabular}

Source: Authors' elaboration with data from World Bank 2014

A further indicator aims at the financial sector with regard to the ratio of M2 to foreign exchange reserves; the rule of thumb is considered to be 5 . The indicator shows whether countries could solve sudden capital outflows and subsequent problems in exchange rate. Then, this argument would be the reason for the outstanding accumulation of foreign exchange reserves in underdeveloped countries. However, no country in Latin America (except Chile and Venezuela for short periods of time) has exceeded that level on average in the 2000s (see Figure 2). 
Figure 3

Ratio of M2 to foreign exchange reserves. Dotted line $=5$
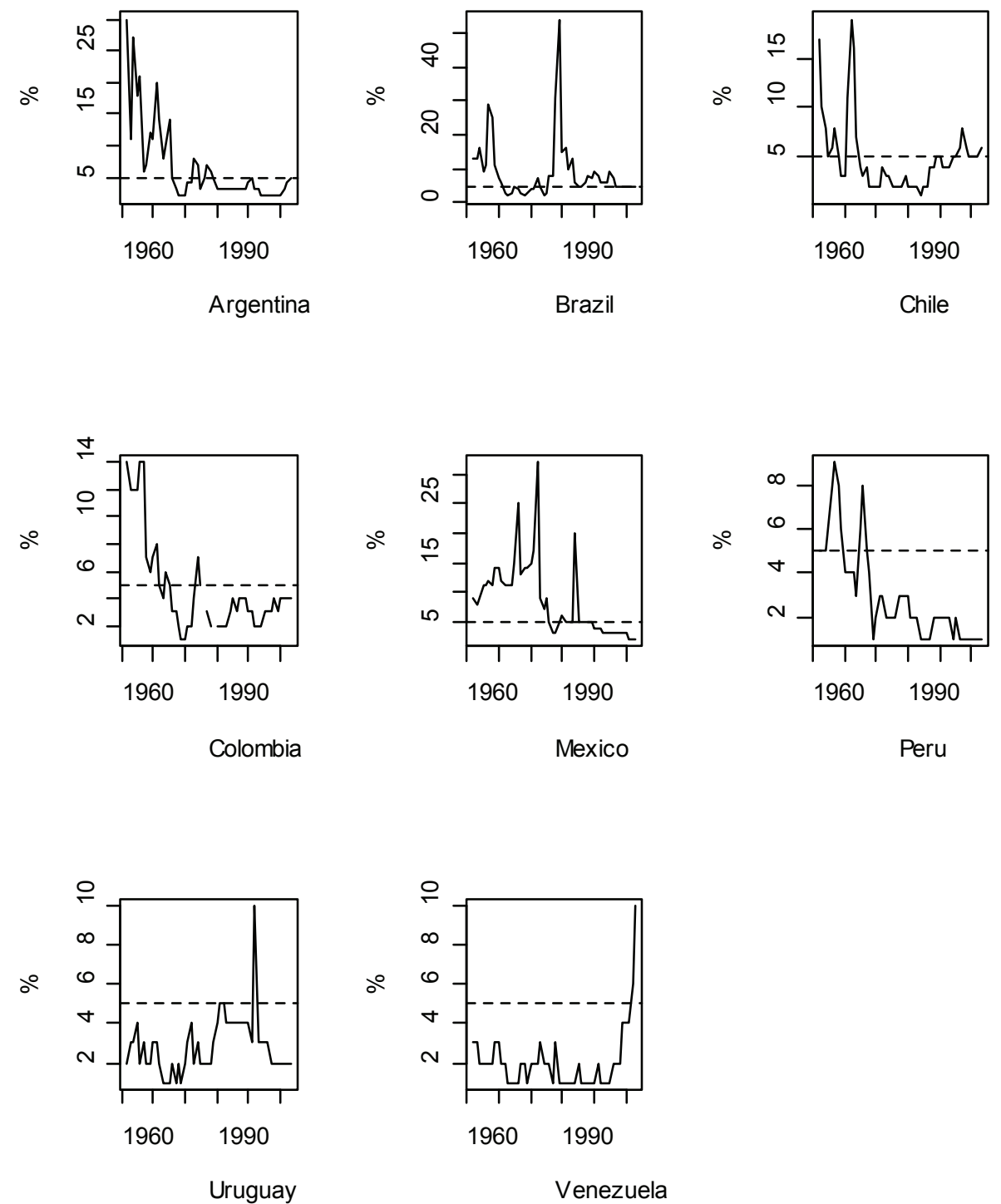

Source: Author's elaboration with data from WorldBank (2014).

Why do Brazil and Mexico, especially, keep up a policy of accumulation of foreign exchange accumulation? According to Aizeman and Lee (2006), accumulation of foreign exchange is a neomercantilist policy that was practiced in Japan and Korea. Two types of neomercantilism are distinguished: (1) mo- 
netary mercantilism and (2) financial mercantilism. The first is compounded on competitive depreciations among underdeveloped countries, which produces an economic policy beggar-thy-neighbor with negative externalities for other countries. The second is based on supporting export sectors increasing their productivity. The two measures seek a positive trade balance, to hoard and promote economic growth. However, except for Chile, Peru, and Venezuela, no country in Latin America has had persistent trade surpluses and none of them has had persistent economic growth. It is well known that Latin American countries benefited from the early 2000's boom in commodities. Neither trade surpluses during that period because of competitive depreciations, nor increases in neither productivity, nor hoarding were used to spark an industrialization process.

As already mentioned, Rodrik (2006) provides an explanation called selfinsurance protection against the capital outflows or changes in the exchange rate that may lead to a crisis. He also notes two types of costs involved in hoarding international reserves: (1) the spread between "the private sector's cost of short-term borrowing abroad and the yield that the Central Bank earns on its liquid foreign assets" (Rodrik 2006, 7) such as T-bills; and (2) the loss of buying T-bills instead of increasing the stock of capital or social spending (antipoverty programs).

Some post-Keynesian scholars argue in the same vein considering the last point: As long as international reserves go beyond 5 or 6 percent of GDP, the surplus can be used to increase the stock of capital (Cruz 2006). PostKeynesian scholars also comment that capital controls and not the increase of foreign exchange reserve prevent outflow of capital and exchange rate problems (Grabel 2003; Cruz 2006). Of course, increases in the stock of capital as well as capital controls may be desirable, but this position neglects the fact that institutions in each underdeveloped country are embedded, and that to establish capital controls in all the countries as in the Golden Age is not possible right now, given the correlation of forces among the elite and between the elite and working class. Also, post-Keynesian scholars forget the evolution of the profit rate.

Some Marxists (Lapavitsas 2013; Labrinidis 2014) notes that accumulation of foreign exchange is due to the function of money as world money. Certain currencies, therefore, go beyond their national space and serve as an international means of payment and hoarding. Advanced countries with quasi-world money, such as the Us, Germany, and Japan have to keep a certain amount of foreign exchange reserves. Meanwhile, underdeveloped countries that intend 
to have quasi-world money have to hoard vast amounts of foreign exchange reserves. Labrinidis (2014) and Persaud (2004) point out that China is the leading candidate to have quasi-world money in the future. That this argument may be valid for China, but not for Brazil and other Latin American countries, makes sense, because there are other economic and institutional factors that might influence whether a currency is quasi- world money (Lapavitsas 2006). Among these factors are economic growth and an army. However, the function of hoarding can give each country the appearance of strength. As Marx notes (1946; 1980), hoarding damages the industrial capitalist and leads an economy towards deflation, but in some ancient societies hoarding was the expression of social wealth. Hoarding, then, may also represent power and give weak countries the appearance of strength.

\section{Conclusion}

This article has described the economic performance of Latin America, the us, Germany, and Japan. We found that Latin American countries have grown at a higher rate than some developed countries, but underdeveloped countries have grown through trade, so they needed more than the advanced countries, rather than vice versa. We highlighted the increasing amount in reserves as percent of GDP, especially in Brazil, Mexico, and, Peru, and noted that for some countries, reserves might represent the social expression of wealth and not capacity production.

\section{References}

Aizenman, J., and J. Lee. Financial versus Monetary Mercantilis - long-run View of Large International Reserves Hoarding. Cambridge: NBER, 2006.

Bird, G, y R Rajan. «Too much of a good thing? The adequacy of international reserves in the aftermath of crises.» 26, $\mathrm{n}^{\circ} 3$ (2003): 873-891.

Collier, P., and D.Dollar. Globalization, Growth, and Poverty: Bulding and Inclusive World Economy. Washington: Worl Bank, 2002.

Cruz, M. «¿Pueden las reservas internacional contribuit al crecimiento mexicano?» Economía UNAM 3, no 8 (2006): 115-124.

Cruz, Moritz, y Bernand Walters. "Is the accumulation of international reserves good for development.» Cambridge Journal of Economics, n 32 (2008): 665-681.

Grabel, I. "Averting crisis? Assesing measures to manage financial integration in emerging countries.» Cambridge Journal of Economics 27, nº 3 (2003): 317-336. 


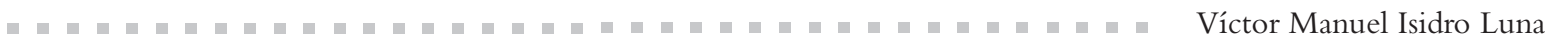

Keen, S. Debunking Economics. The Naked Emperor dethroned. NY: Zed Boks, 2011.

Labrinidis, George. International Reserves in the Era of quasi-World Money. London: SOAS, 2014.

Lanteri, L. «Flujos de capital, choques macroeconómicos y activos de reservas. El caso argentino (1994-2013).» Ecos de Economía 18, nº 38 (2014): 37-61.

Lapavitsas, Costas. Profiting without Financing. How Finance Exploits All. London: Verso, 2013.

Lapavitsas, Costas. «Relations of Power and Trust on Contemporary Finance.» Historical Materialism 14, $\mathrm{n}^{\mathrm{o}} 1$ (2006): 129-154.

Lewis, Arthur. «The Slowing Down of the Engine of Growth.» The American Economic Review 70, no 4 (1980): 555-564.

Marx, Karl. El Capital. Criítica de la economía política. Mexico: FCE, 1946.

Roberts, M. Profits, Cycles, Economic Crisis. A Marxist View. Us, 2009.

Rodrik, D. "The Social Cost of Foreign Exchange Reserves.» International Economic Journal, no 3 (2006): 253-266.

U.S Department of the Treasury. 3 de Semptember de 2014. http://www.treasury.gov/ resource-center7data-chart-center/tic/Pages/index.aspx.

Williamson, John. The Progress of Policy Reform in Latin America. Washington: Institute for International Economics, 1990.

Wolf, M. Why Globalization works. New Haven: Yale University Press, s.f.

WorldBank. World Development Indicators. 15 de March de 2014. http://data.worldbank.org/n. 